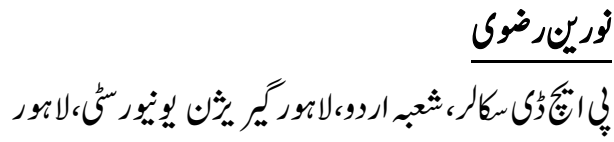

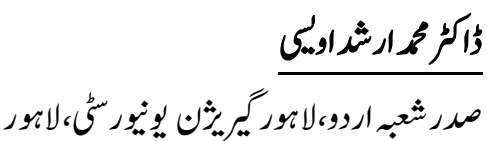

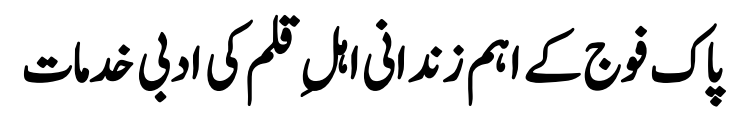

Noureen Rizvi

Ph.D Scholar, Department of Urdu, Lahore Garrison University,

Lahore.

Dr. Muhammad Arshad Ovaisi

Head of Urdu Department, Lahore Garrison University, Lahore.

\title{
Literary Services of Important Prisoner Writers of Pakistan Army
}

Literature is called the criticism of life and it plays important role in shaping the ideas and thoughts of masses. There are different branches of literature and prisoner literature is also branch of literature. When someone punished by Government and put behind the walls of prison, the literature produced in prison is called prisoner literature. Association between military persons and literature has always been very strong and acknowledged in all periods. Pakistan army produces great minds. Armed life is considered as the life of struggle and thrill. The Pakistan army's writers have a great contribution in Urdu literature. They have a great work in Urdu prose and poetry. When Pakistan army's writers and poets are imprisoned, they produce unique and great prisoner literature. The services of prisoner's writers of Pakistan army regarding prisoner literature are highly commendable. In this article some prisoner personalities of Pakistan army and review of their prisoner writings is presented.

Keywords: Pakistan Army, Prisoner literature, Army's Writers, Imprisoned, Contribution, Commendable, Criticism. 


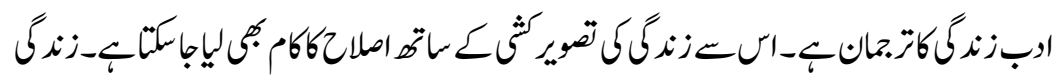

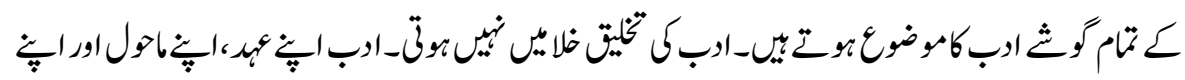

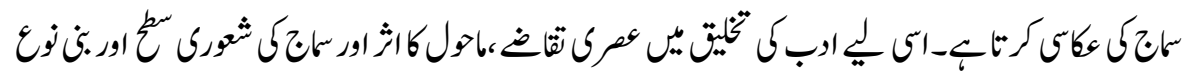

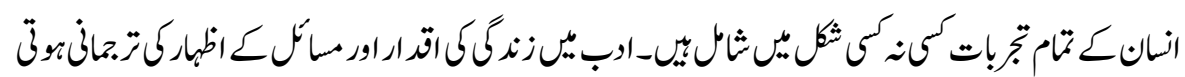

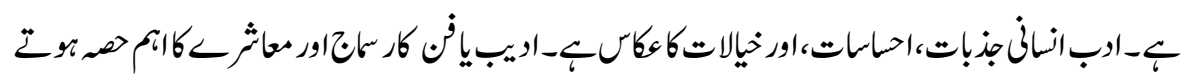

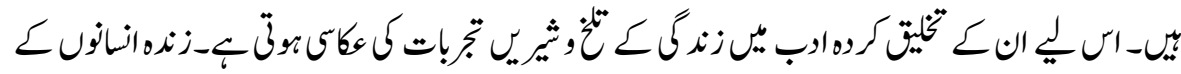

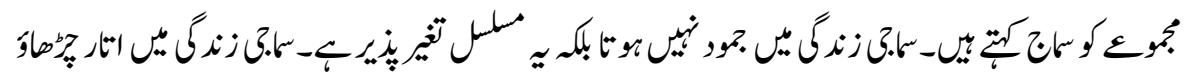

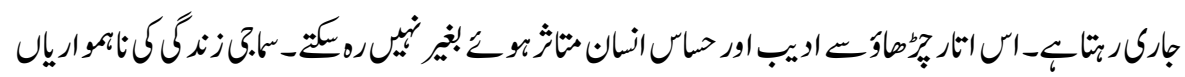

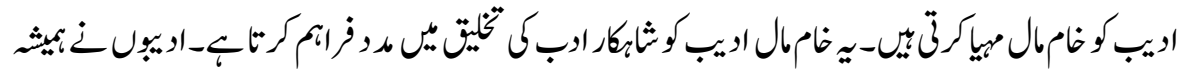

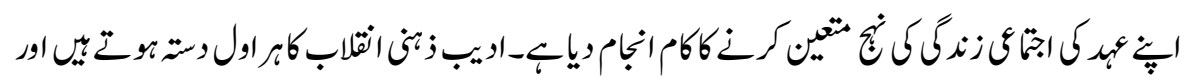

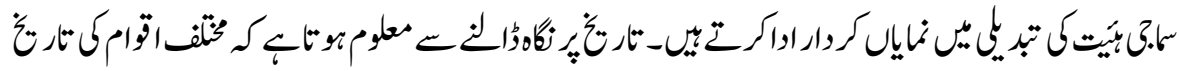

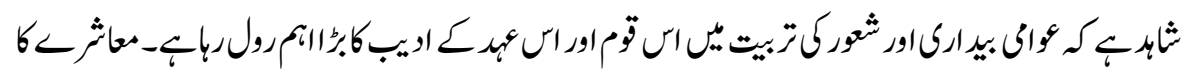

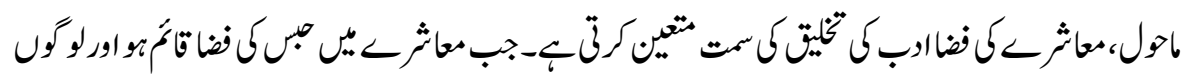

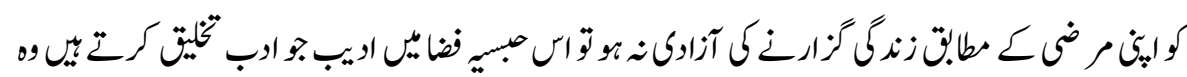

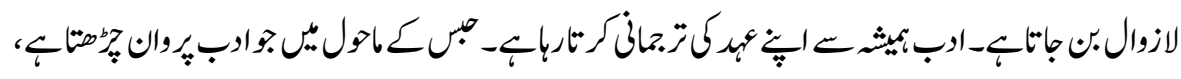

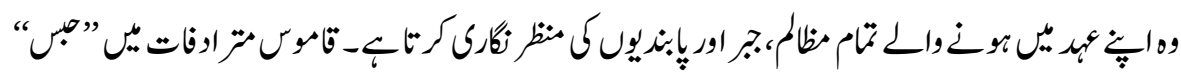

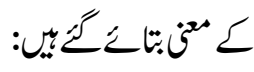

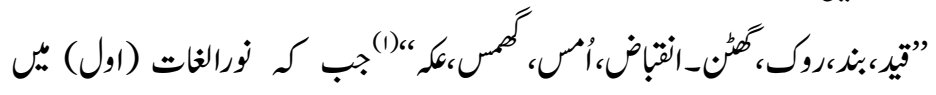

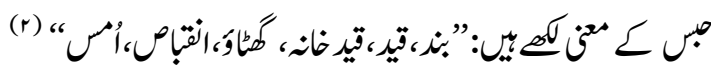

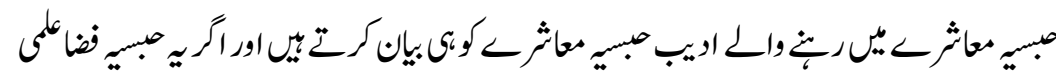

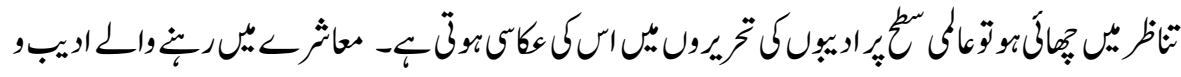

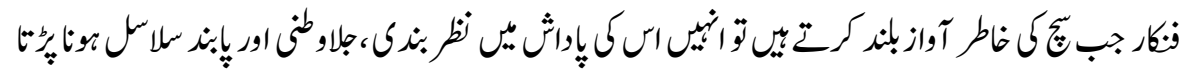

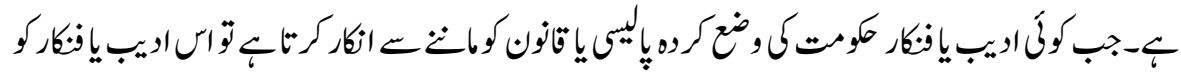




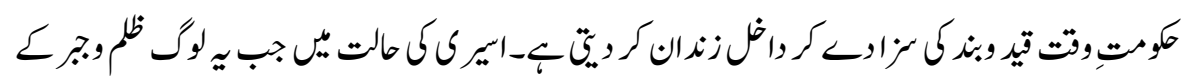

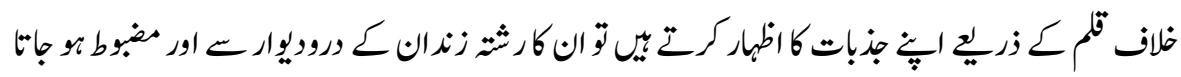

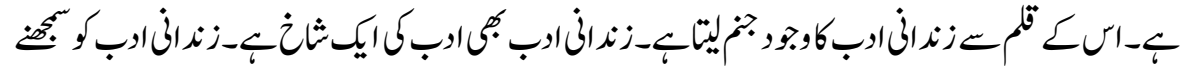

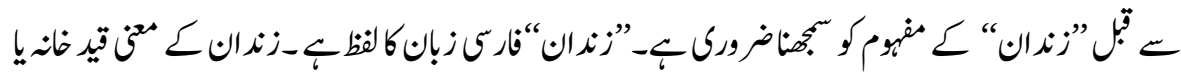

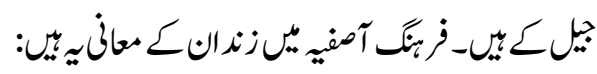

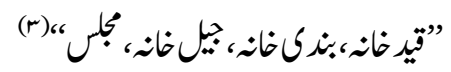

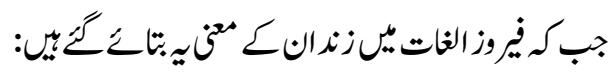

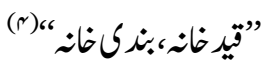

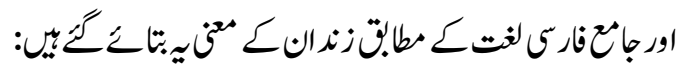

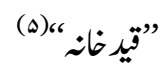

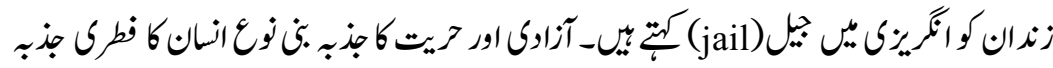

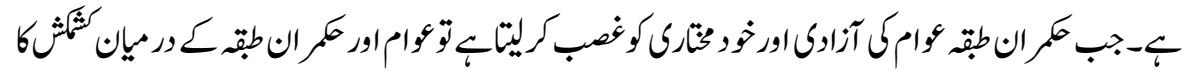

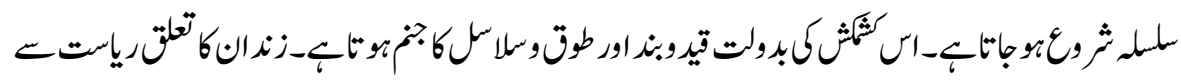

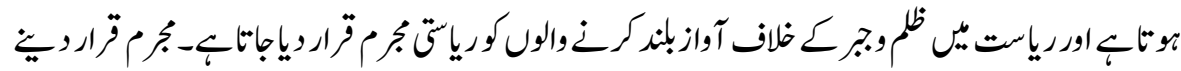

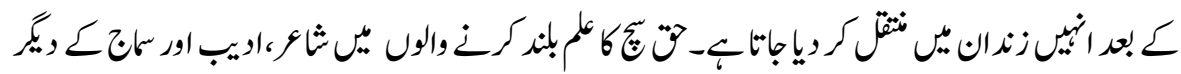

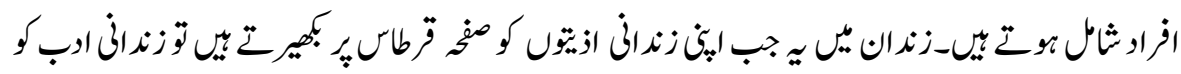

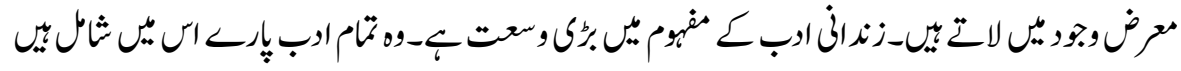

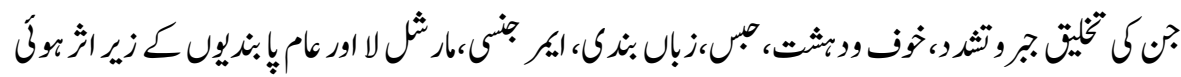

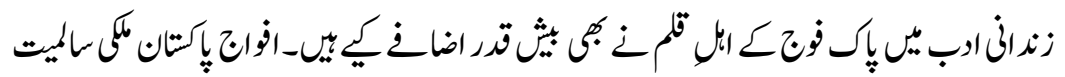

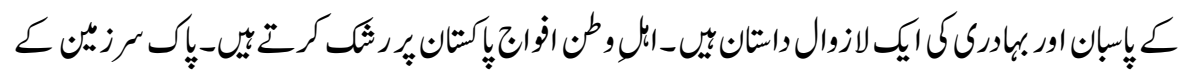

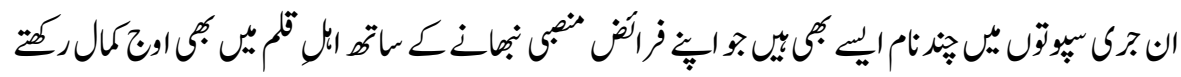

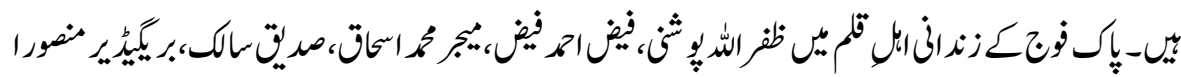




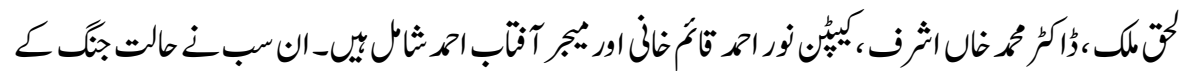

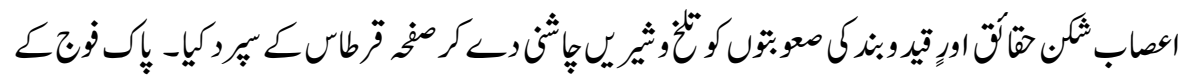

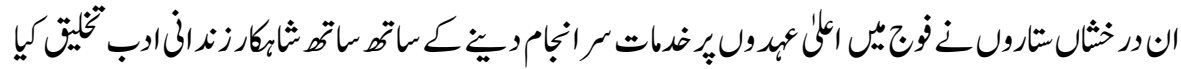

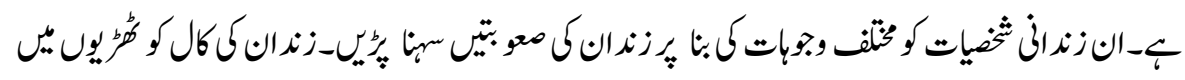

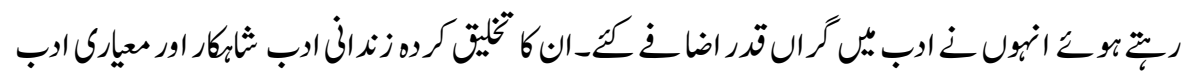
ترارياباسكتمب

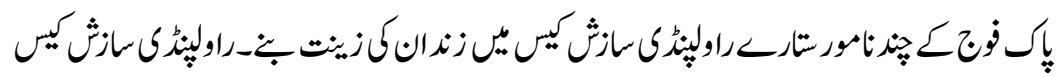

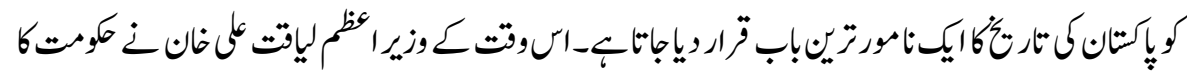

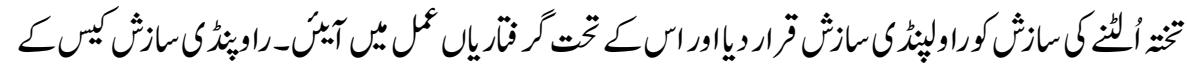

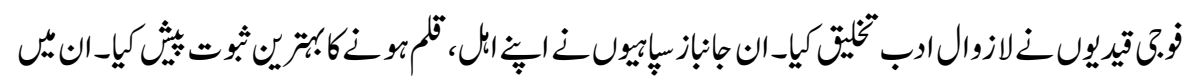

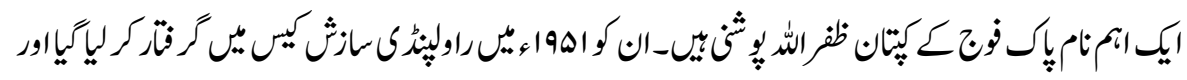

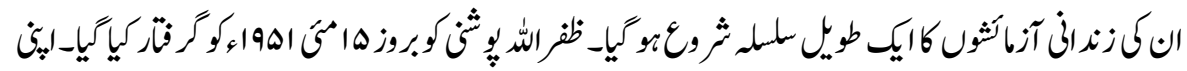

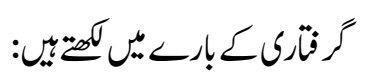

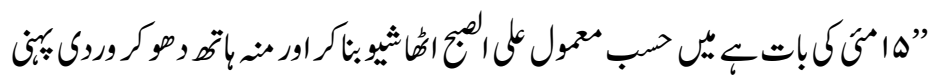

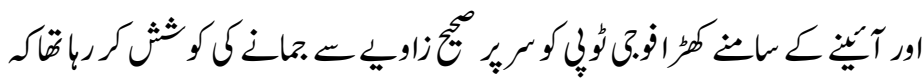

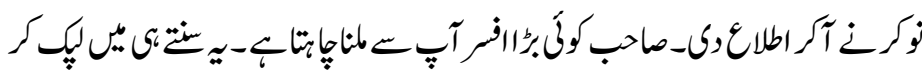

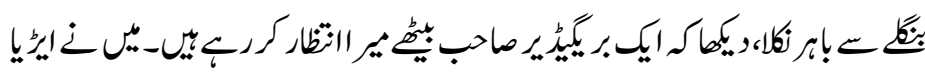

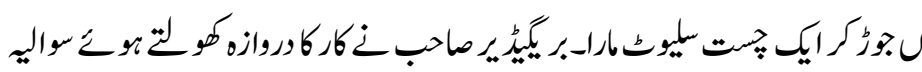

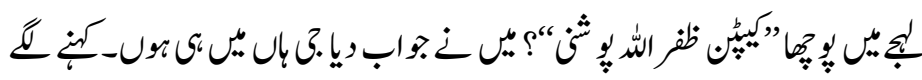

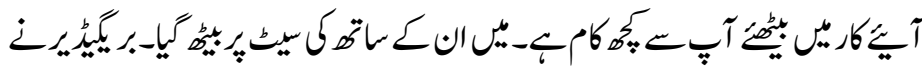

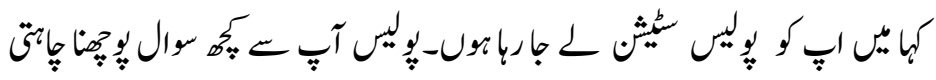




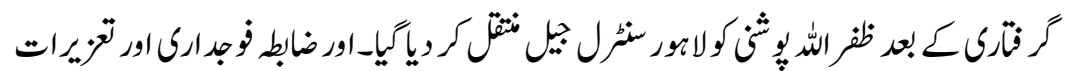

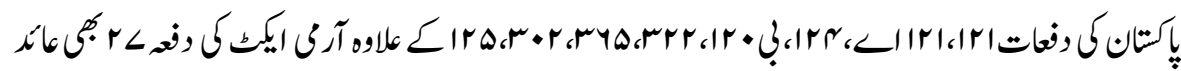

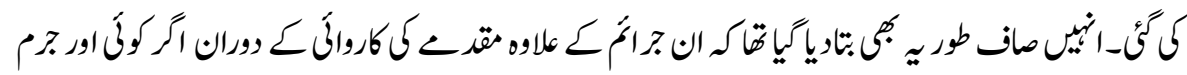

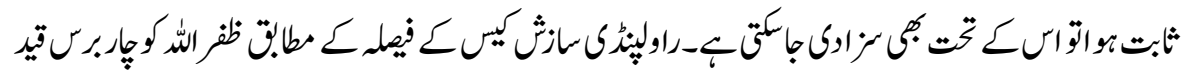

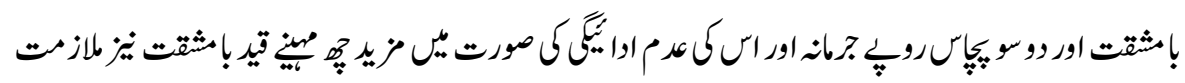

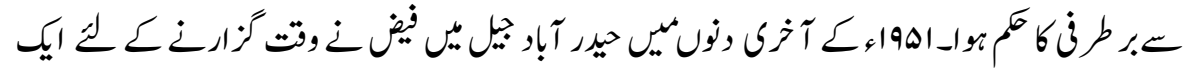

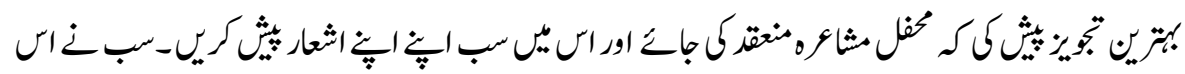

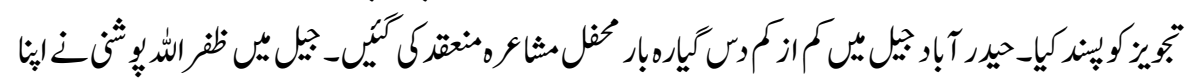

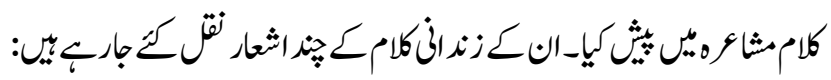

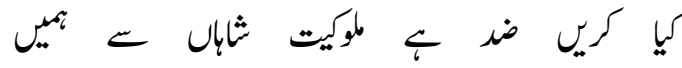

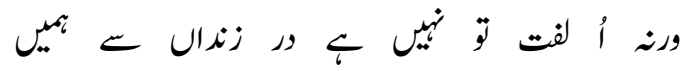

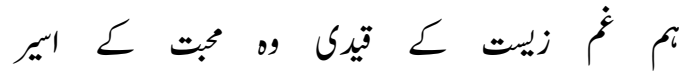

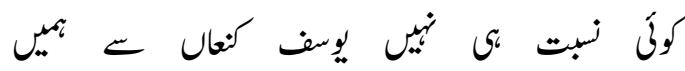

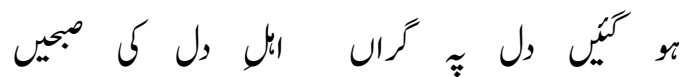

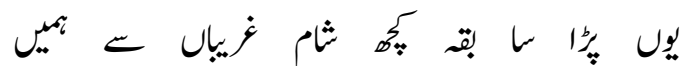

$$
\begin{aligned}
& \text { كام }
\end{aligned}
$$

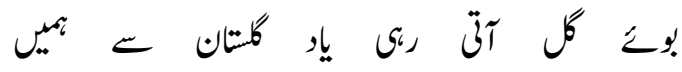

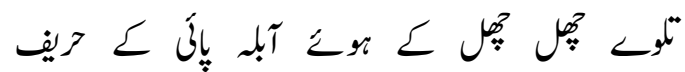

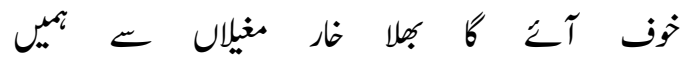

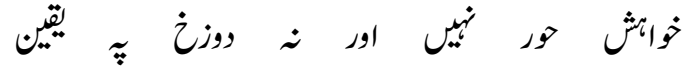

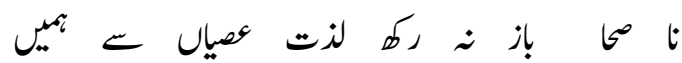

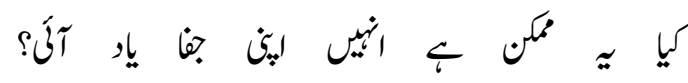

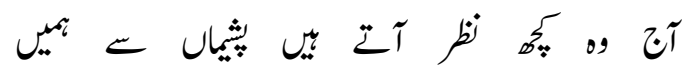


ISSN (Print): 2709-9636 | ISSN(Online) : 2709-9644 | ISSN-L : 2709-9636

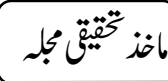

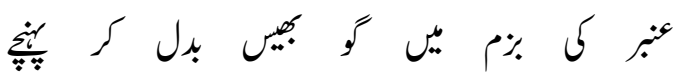

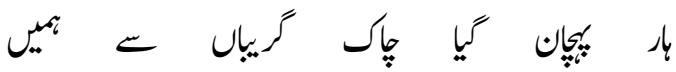

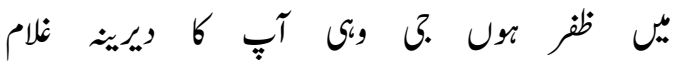

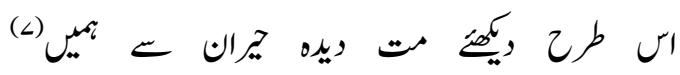

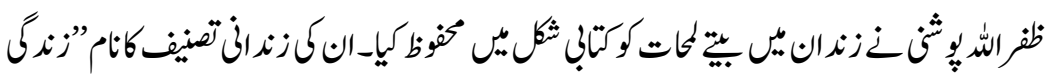

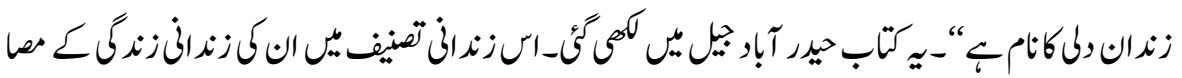

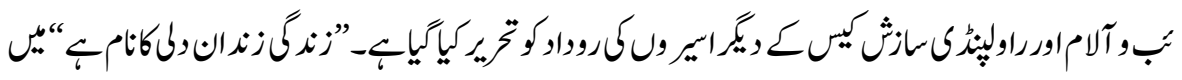

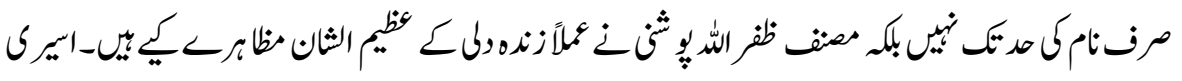

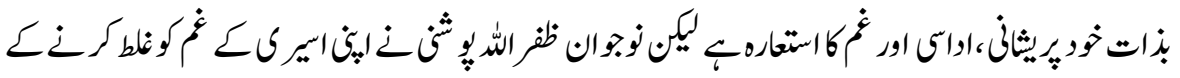

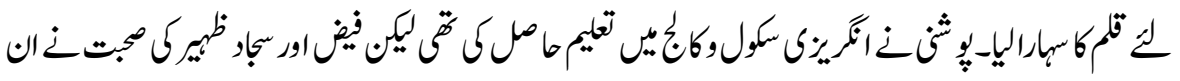

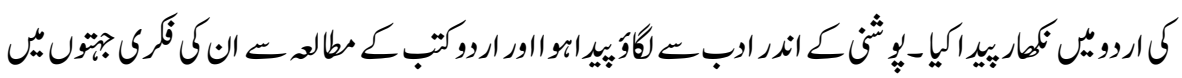

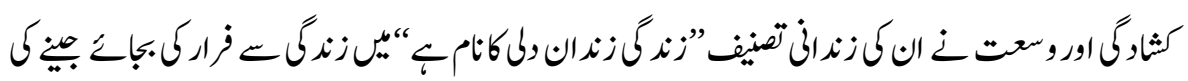

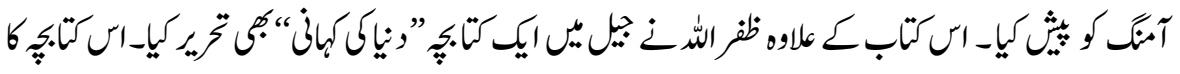

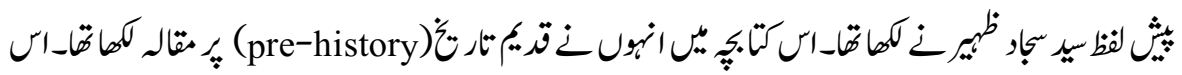

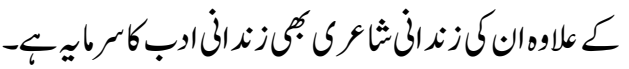

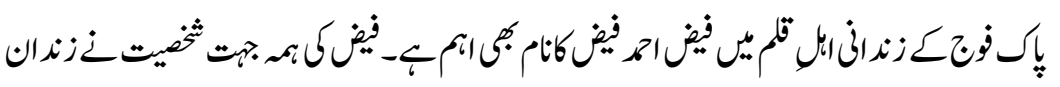

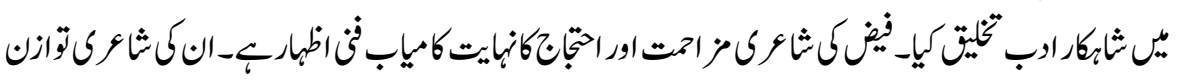

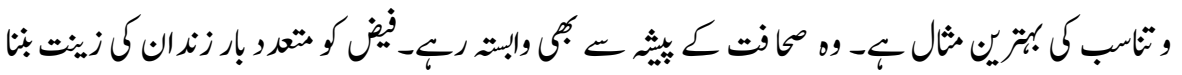

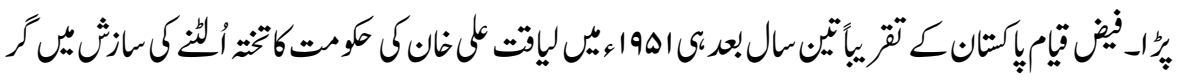

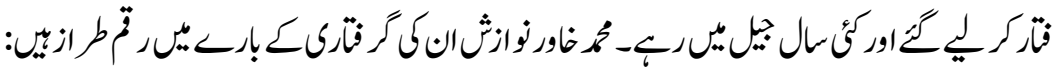

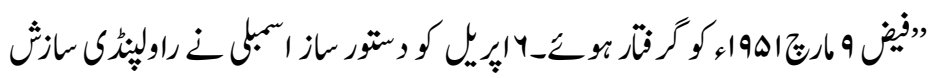

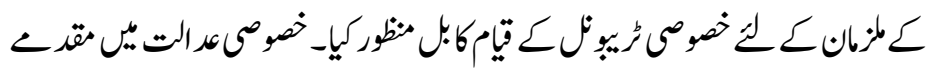

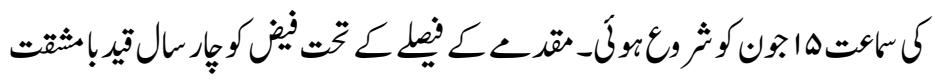

19. 


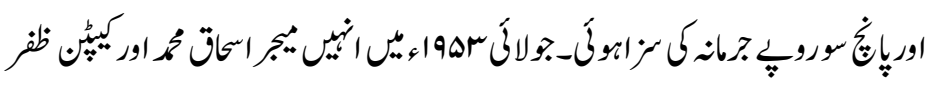

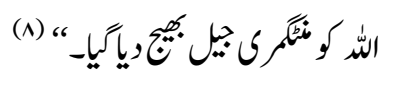

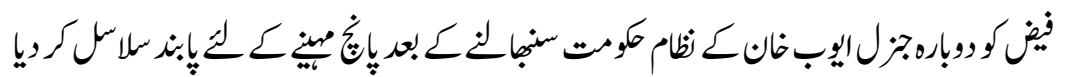

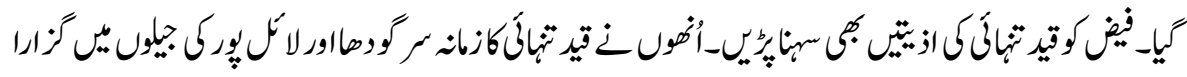

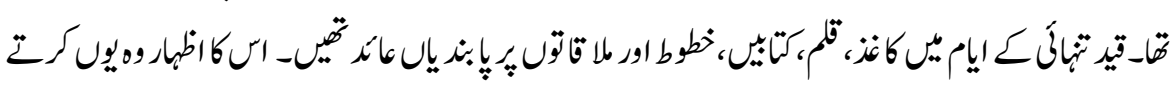

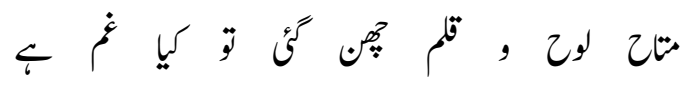

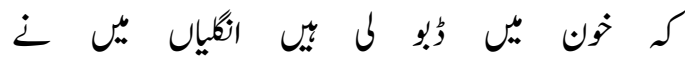

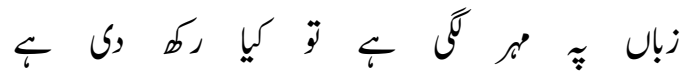

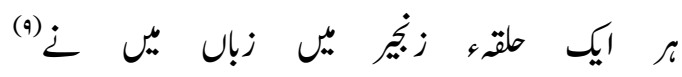

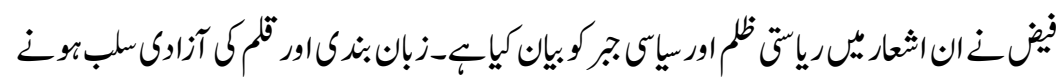

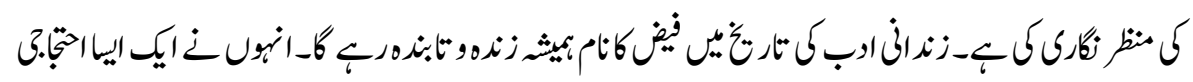

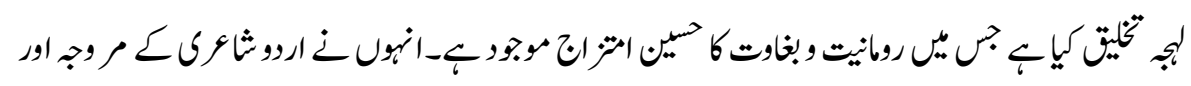

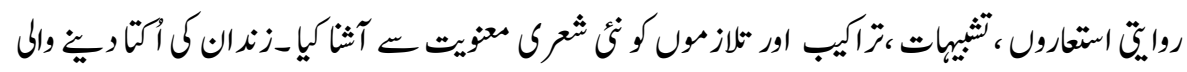

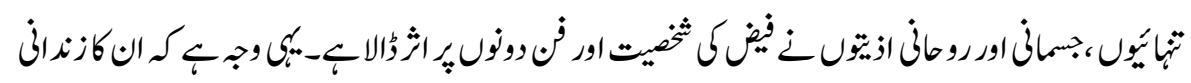

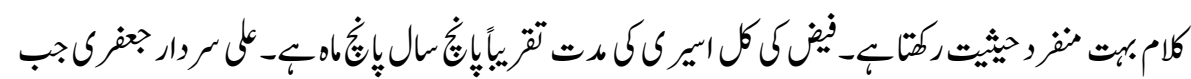

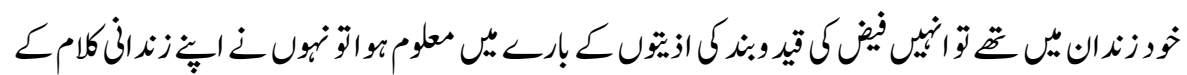

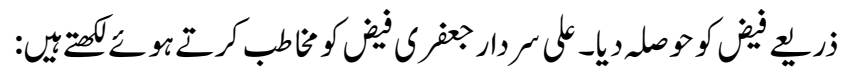

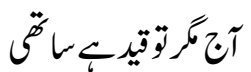

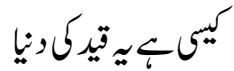

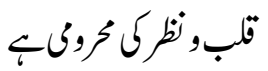

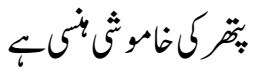




$$
\begin{aligned}
& \text { آنجبجباتونيل تئنا } \\
& \text { يّ ائن آوازكاشعلم }
\end{aligned}
$$

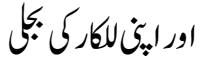

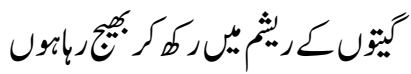

$$
\begin{aligned}
& \text { تيركاناط ثيجربانوب } \\
& \text { يميرك آوازب ليكن } \\
& \text { مرف نير آنواز"نيد }
\end{aligned}
$$

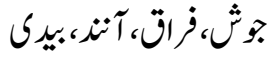

$$
\begin{aligned}
& \text { عصمت،ساح،كرثن اور كيفي }
\end{aligned}
$$

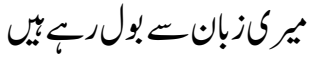

$$
\begin{aligned}
& \text { تنه } \\
& \text { اينّمبت ع كلدست }
\end{aligned}
$$

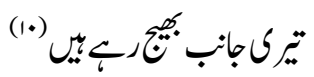

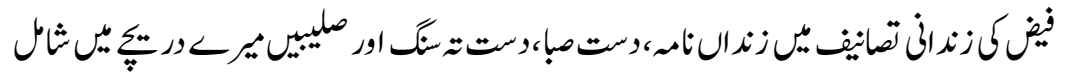

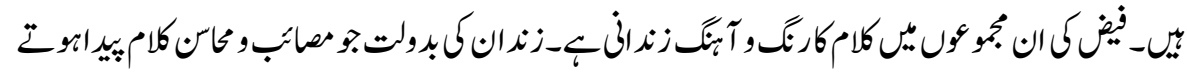

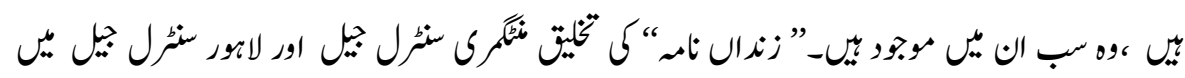

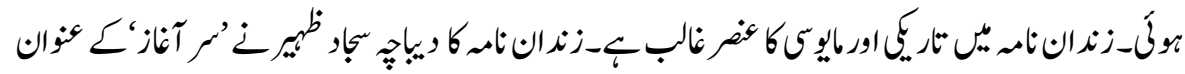

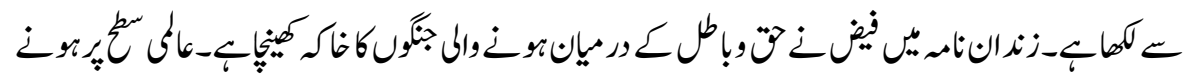

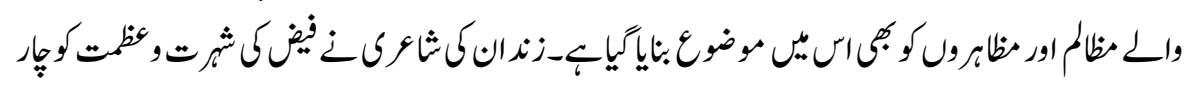

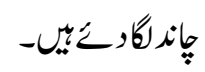

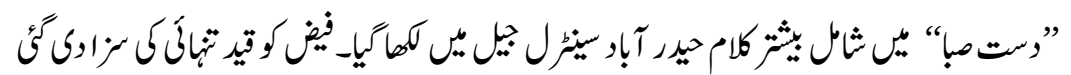

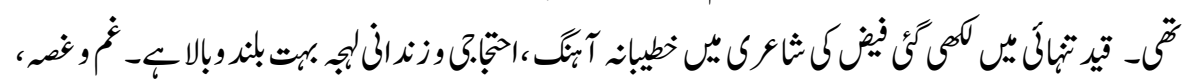

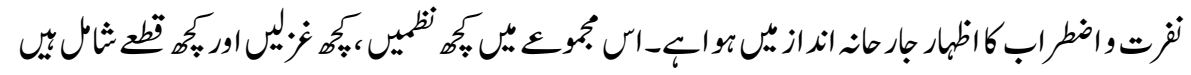




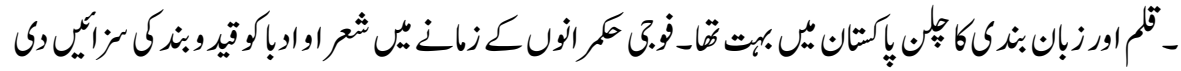

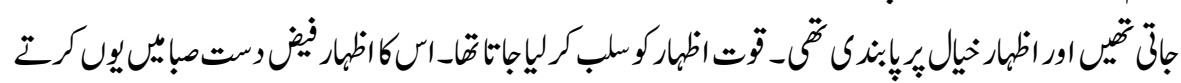
بئ

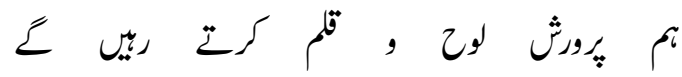

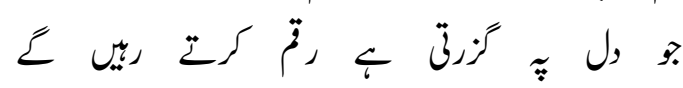

الباب

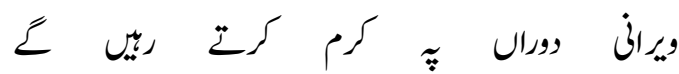

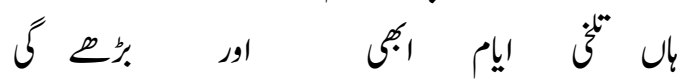

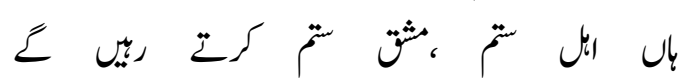

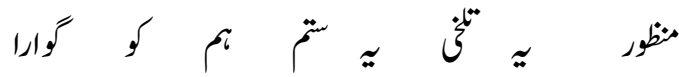

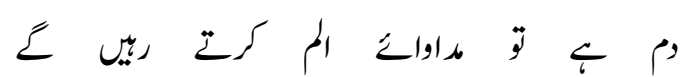

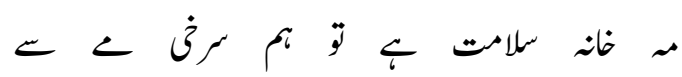

₹

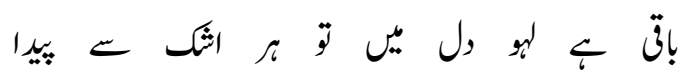

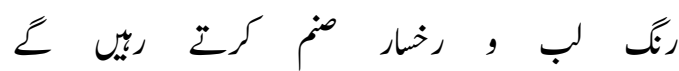

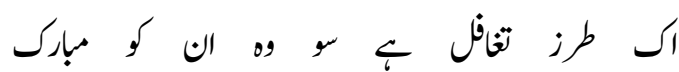

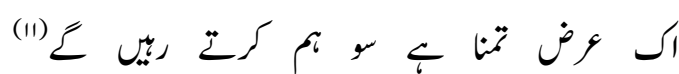

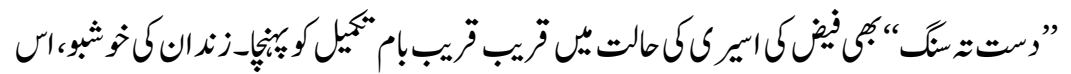

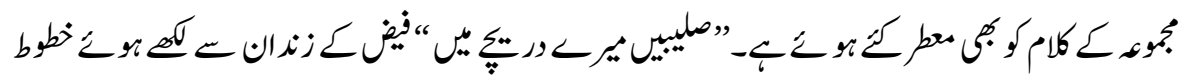

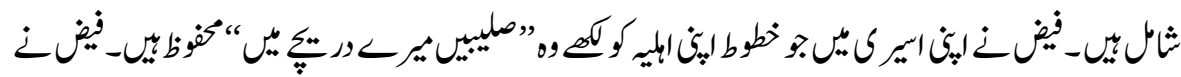

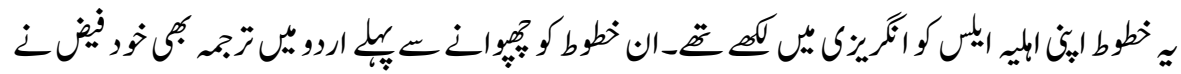

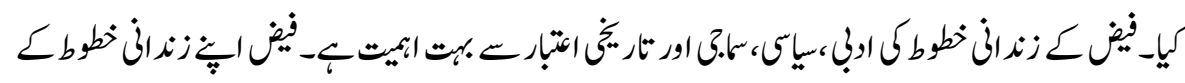

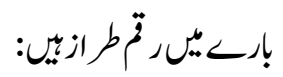




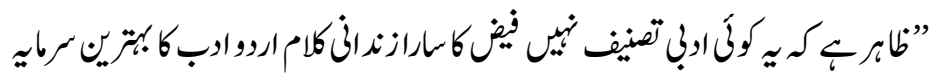

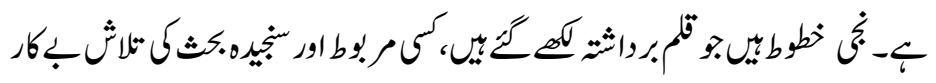

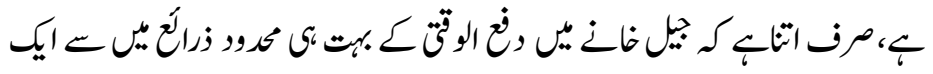

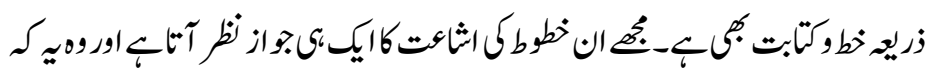

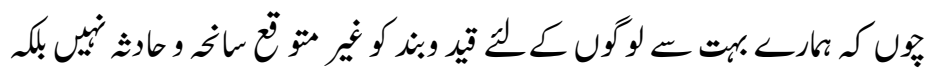

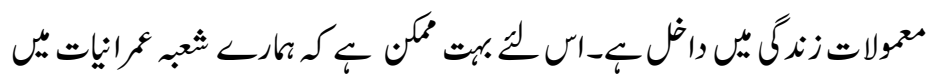

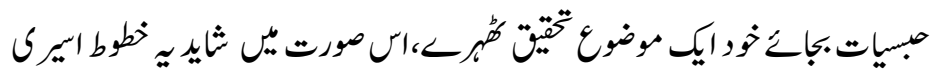

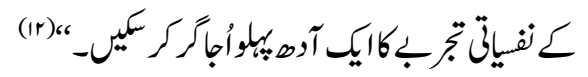

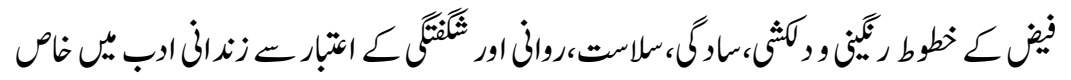

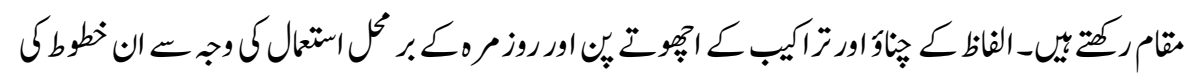

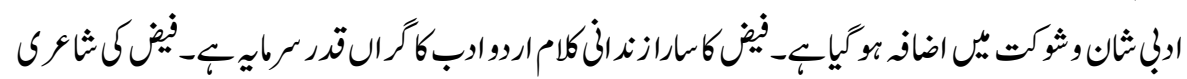

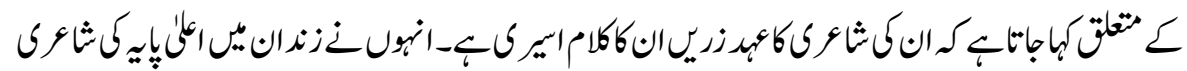

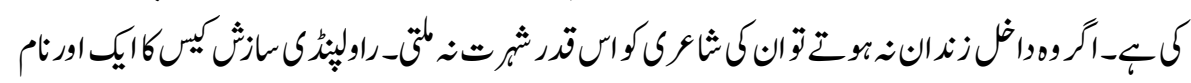

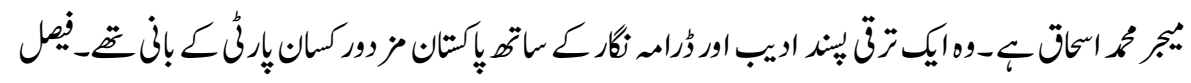

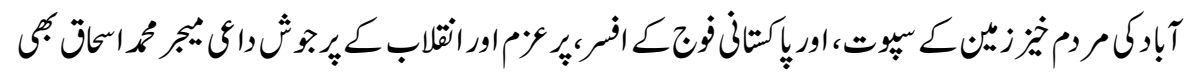

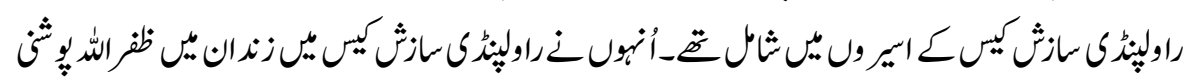

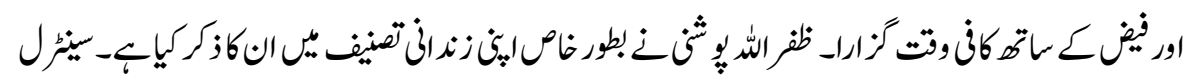

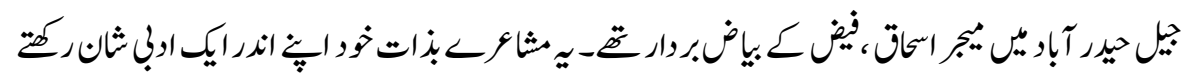

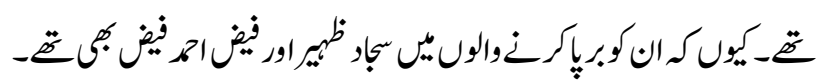

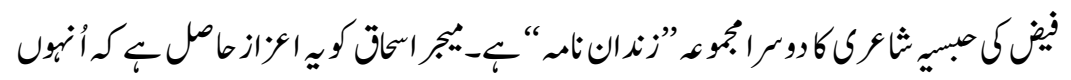

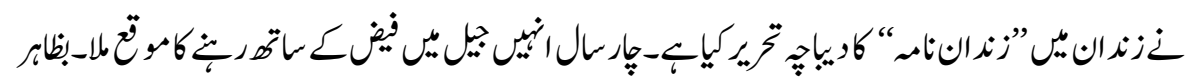

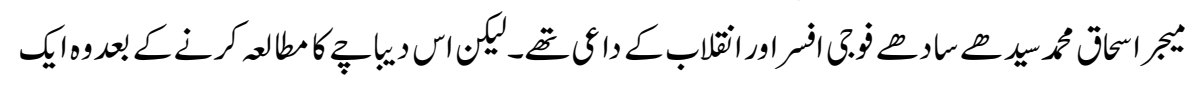

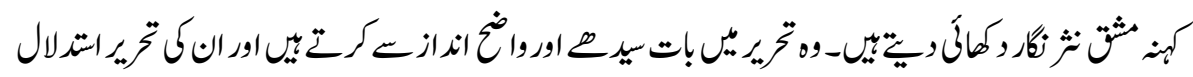




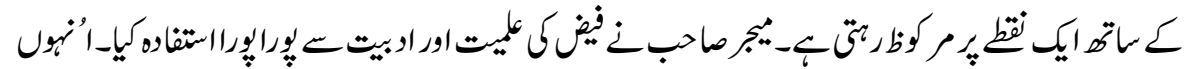

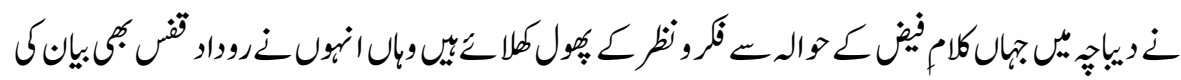

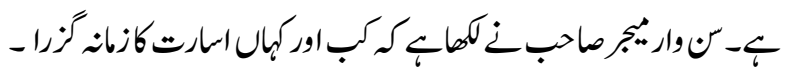

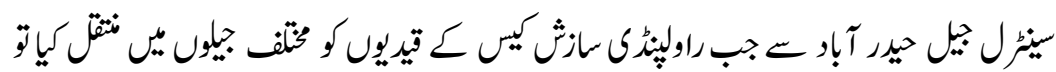

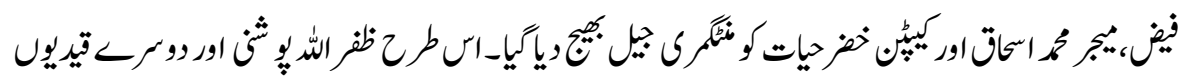

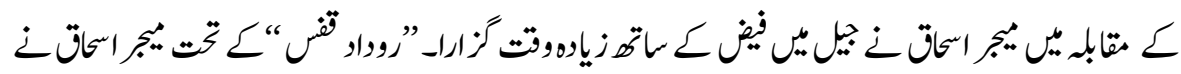

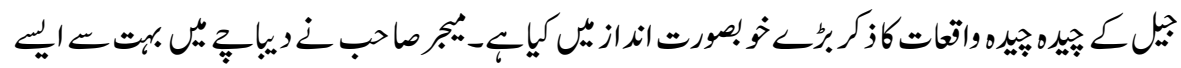

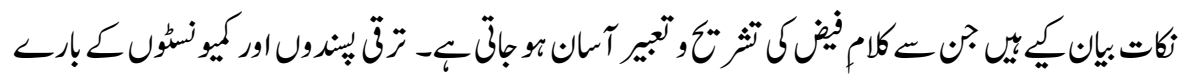

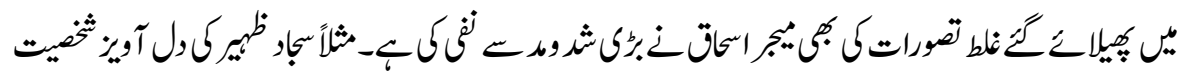

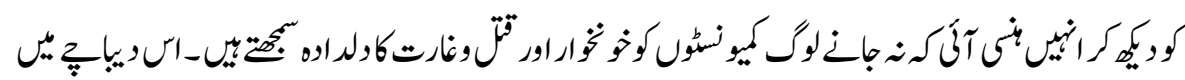

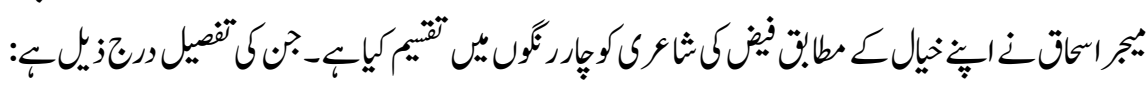

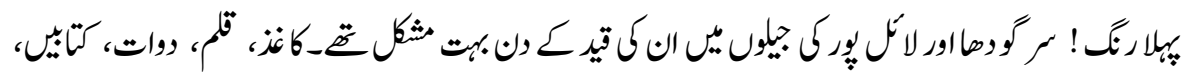

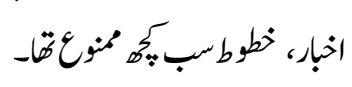

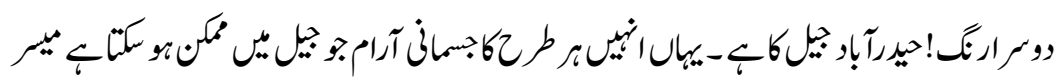

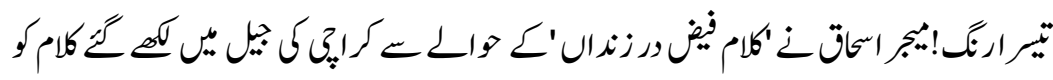

$$
\text { تئرارنَ قراروياب- }
$$

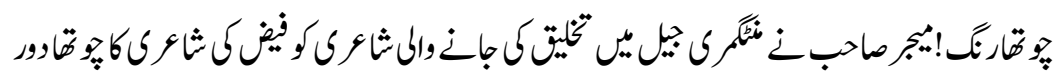

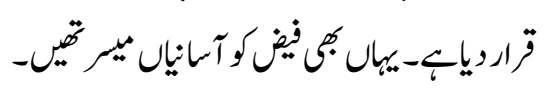

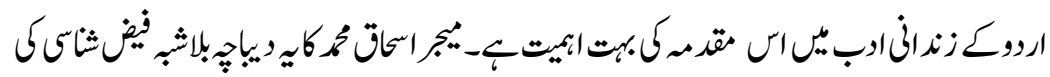

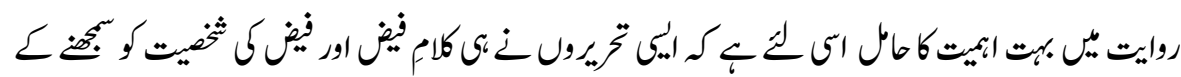

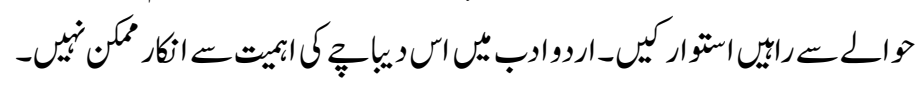




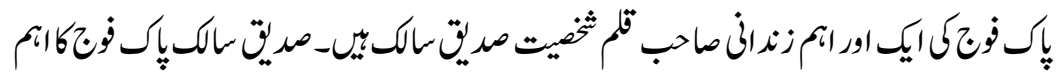

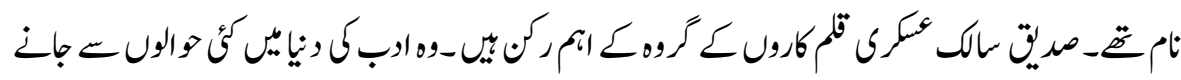

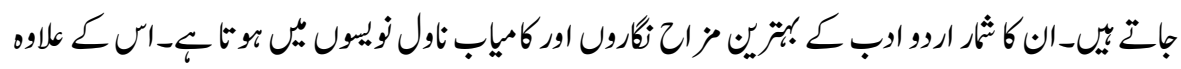

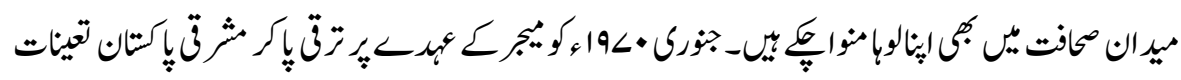

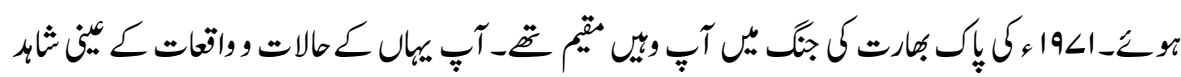

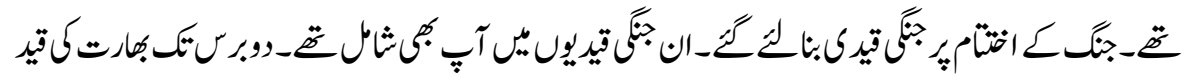

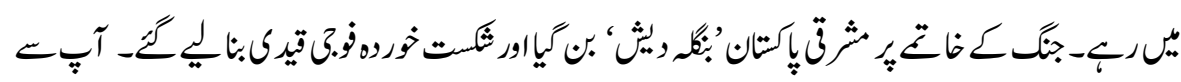

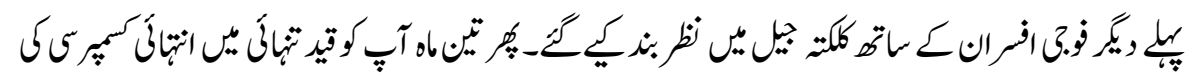

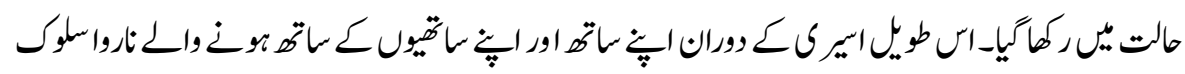

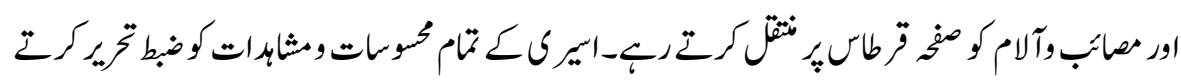

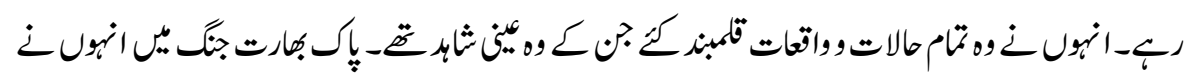

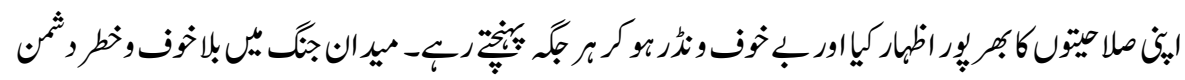

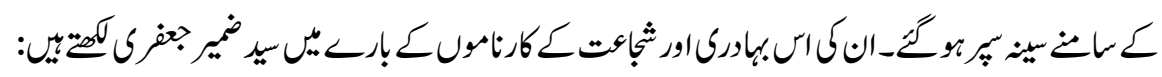

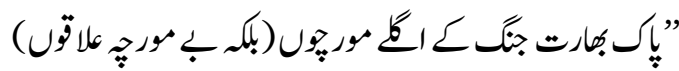

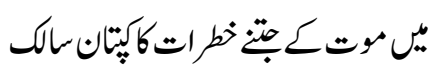

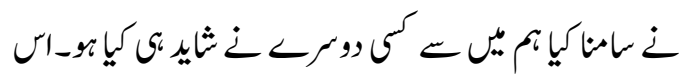

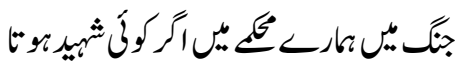

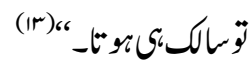

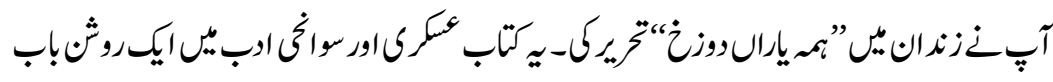

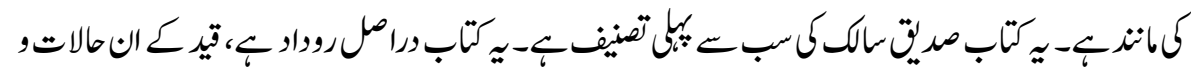

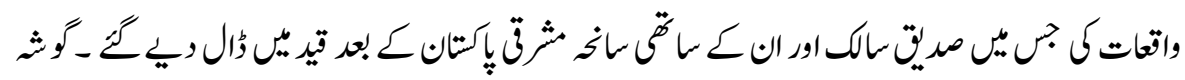

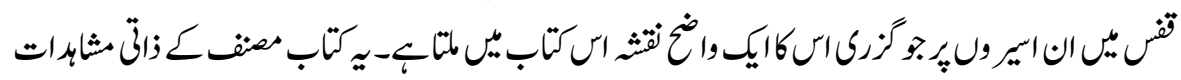

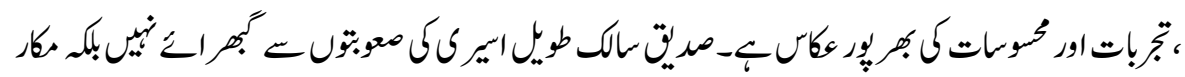




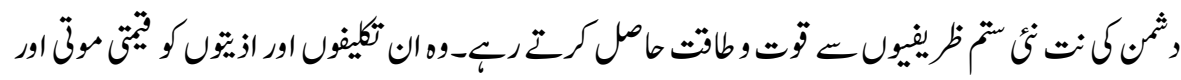

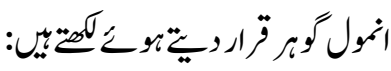

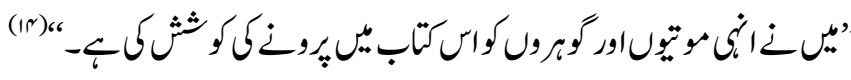

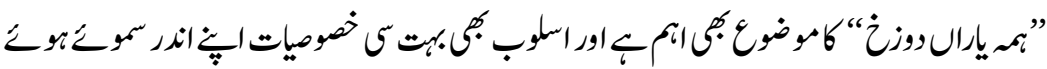

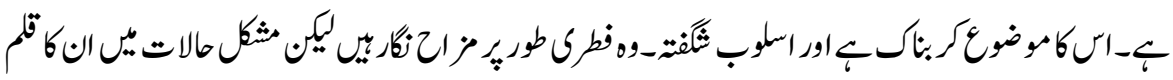

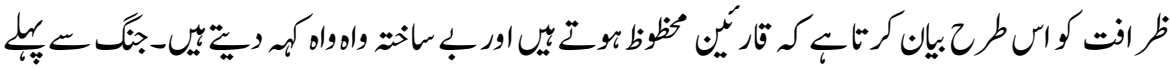

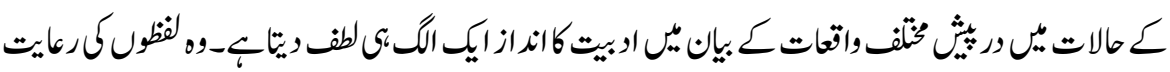

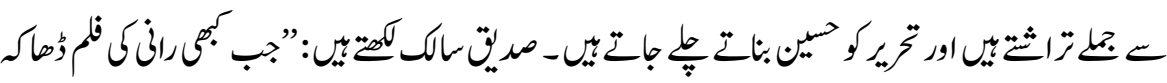

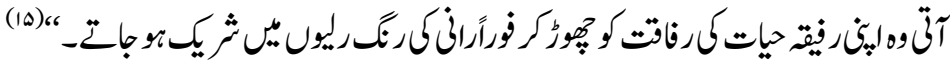

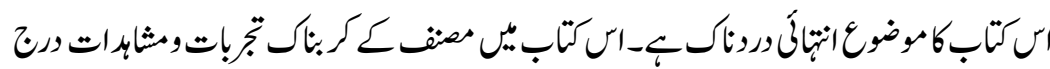

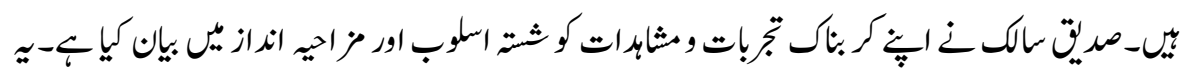

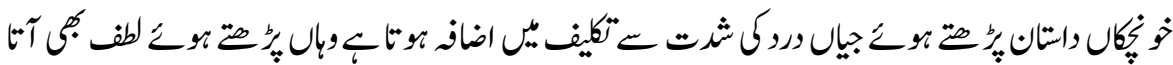

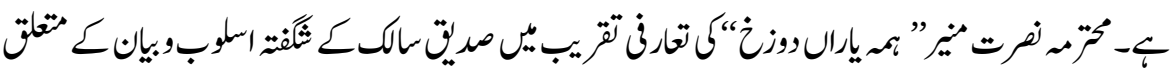
زماني:

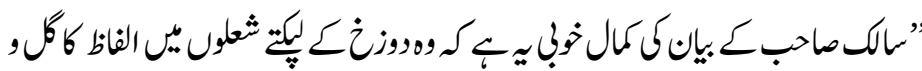

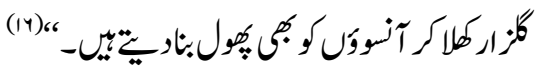

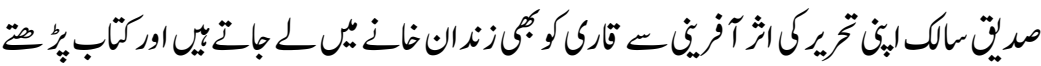

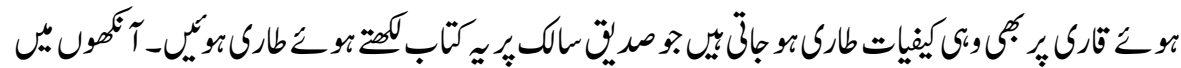

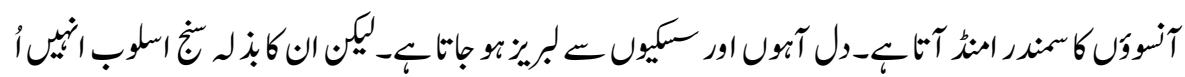

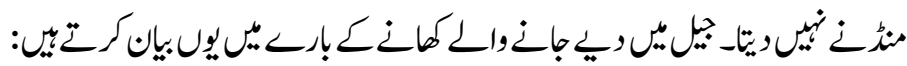

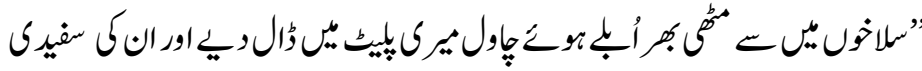

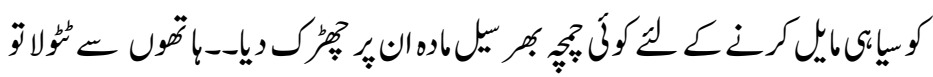




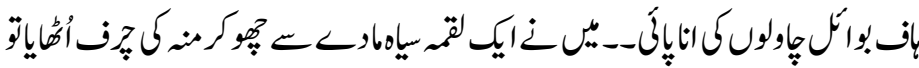

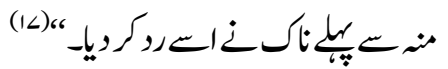

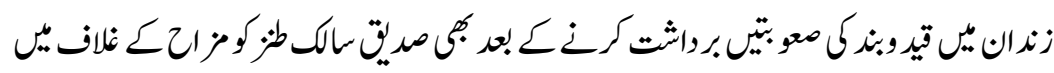

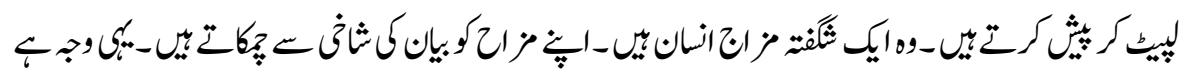

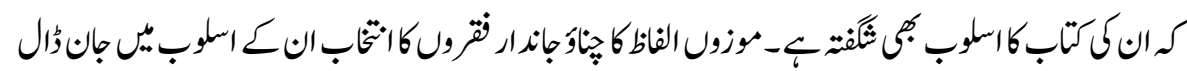

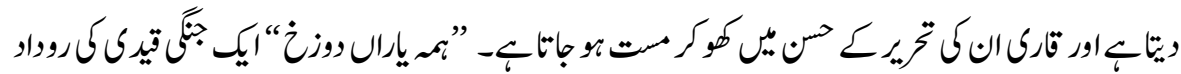

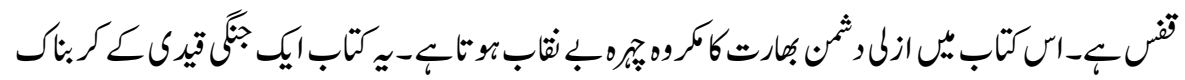

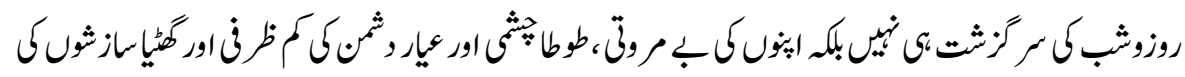

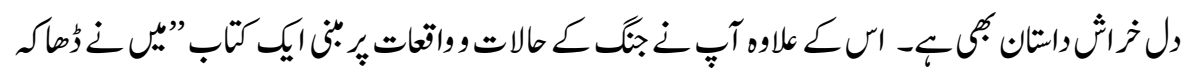

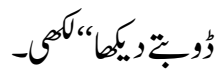

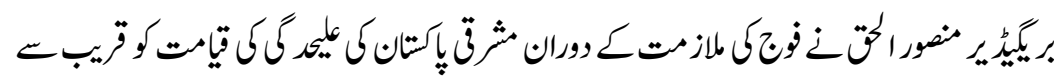

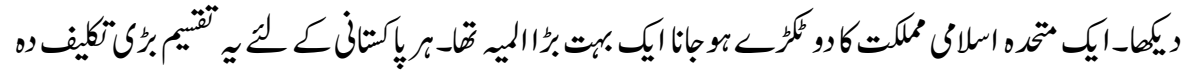

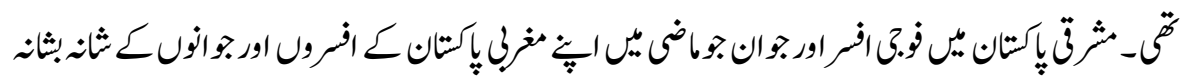

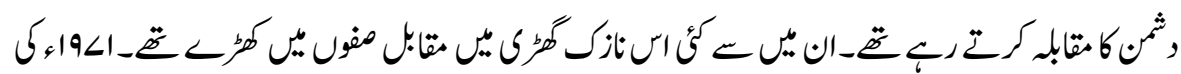

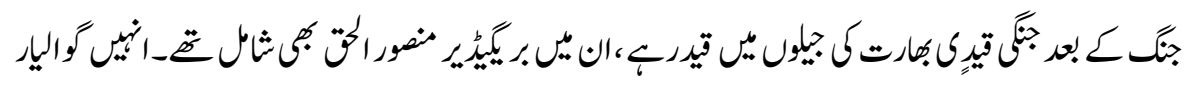

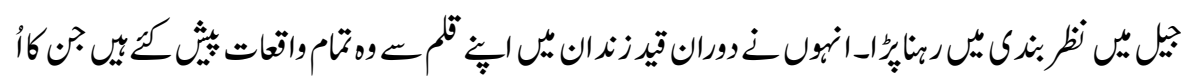

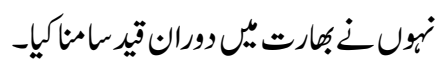

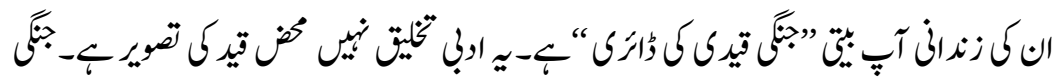

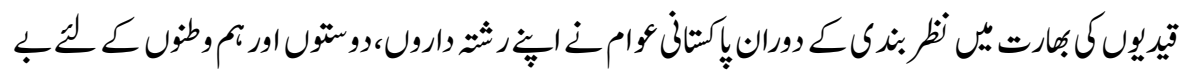

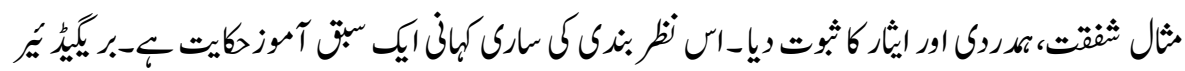

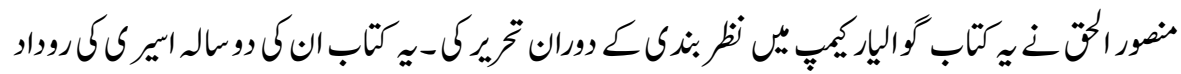

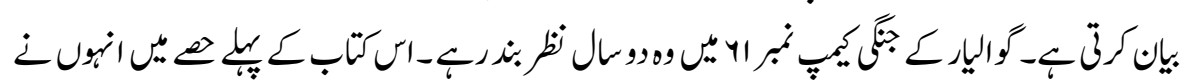

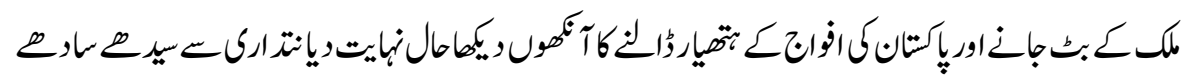




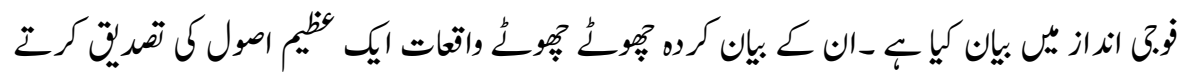

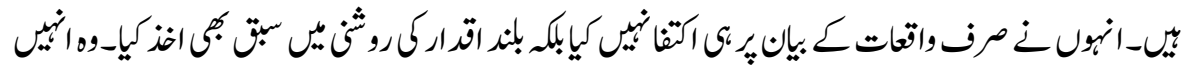

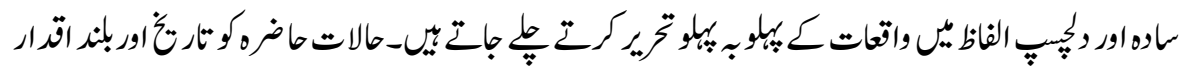

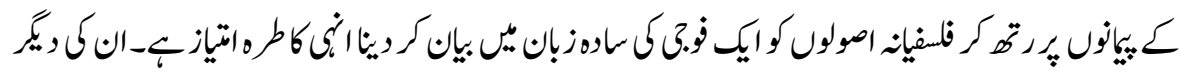

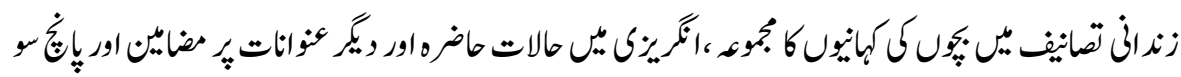

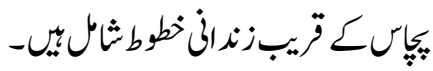

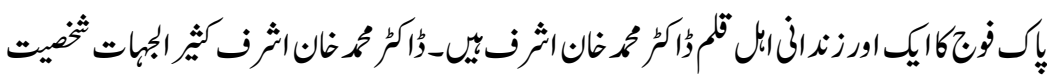

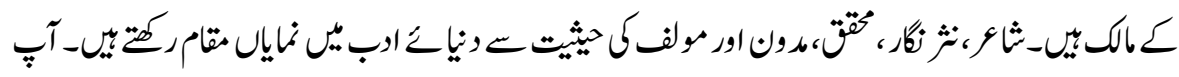

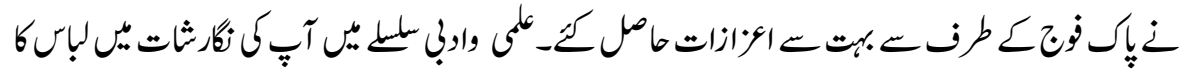

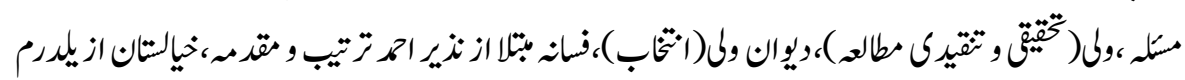

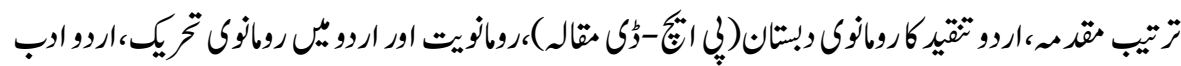

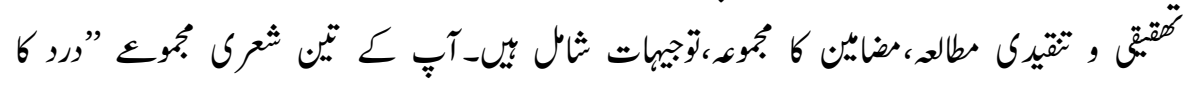

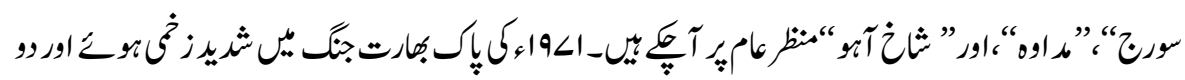

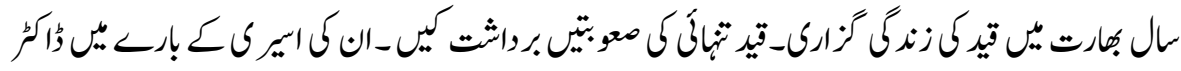

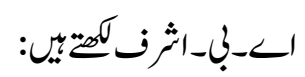

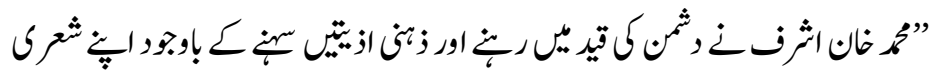

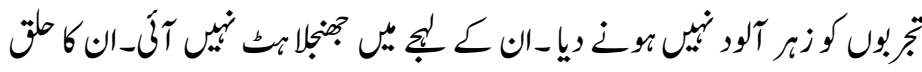

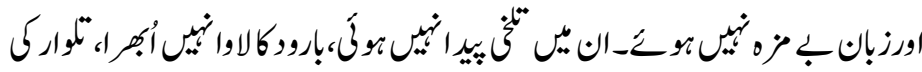

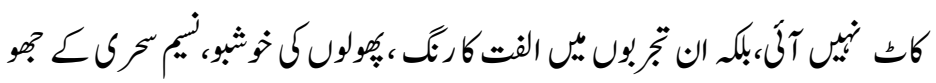

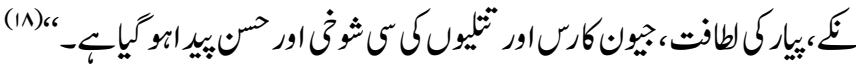

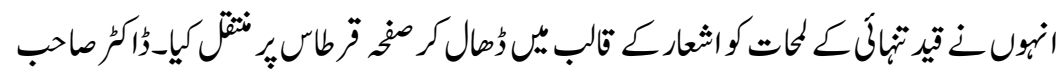

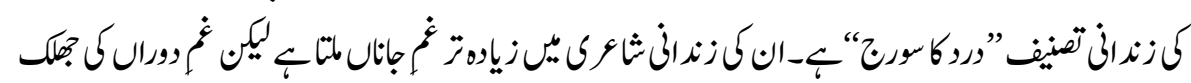

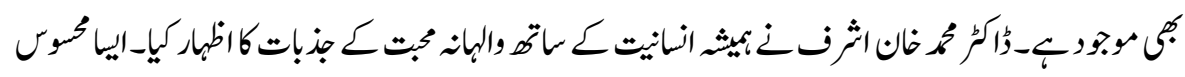




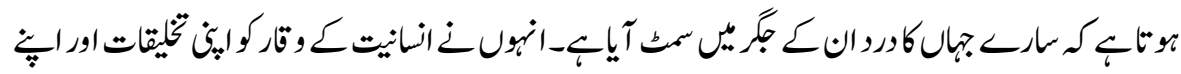

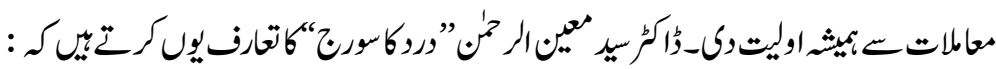

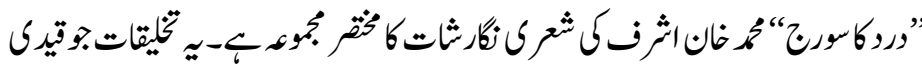

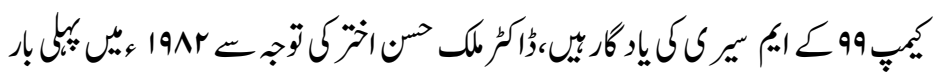

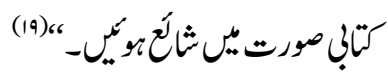

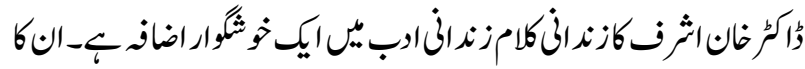

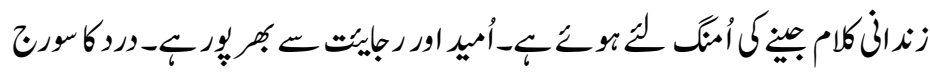

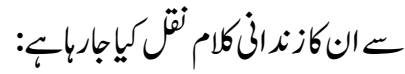

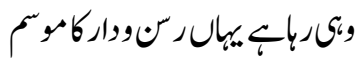

$$
\begin{aligned}
& \text { مكوفاولكمات كير بياركاموسم }
\end{aligned}
$$

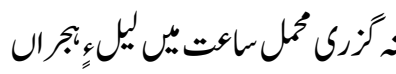

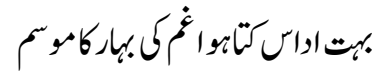

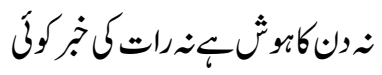

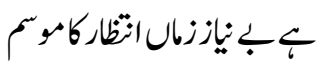

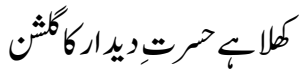

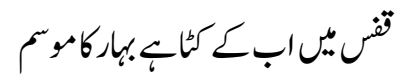

$$
\begin{aligned}
& \text { جولكنجير بردرولاوواكني }
\end{aligned}
$$

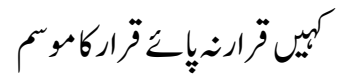

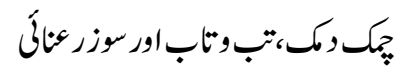

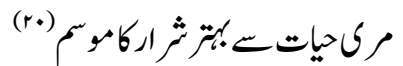

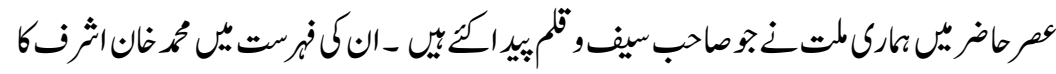

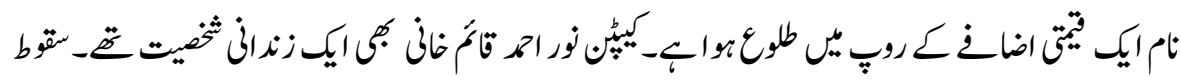

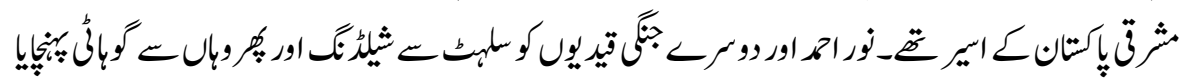




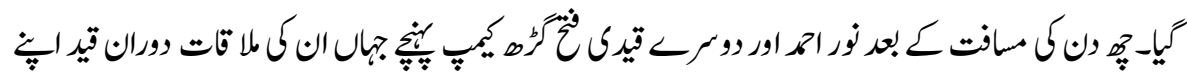

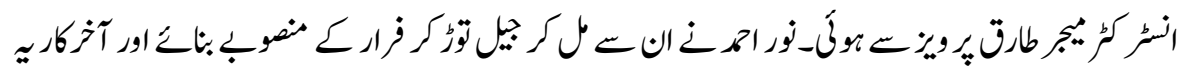

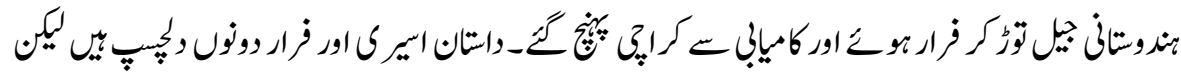

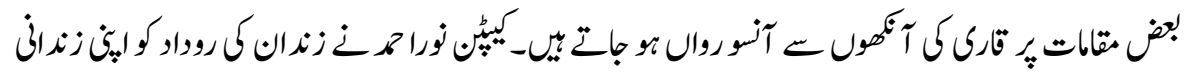

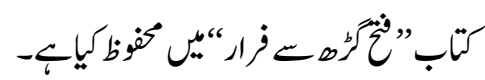

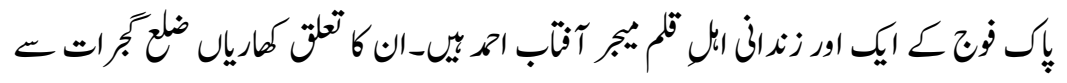

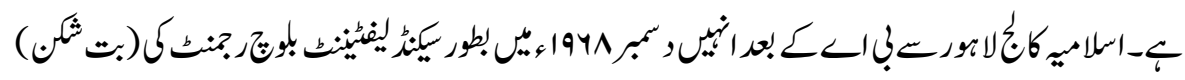

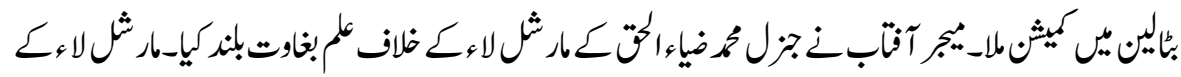

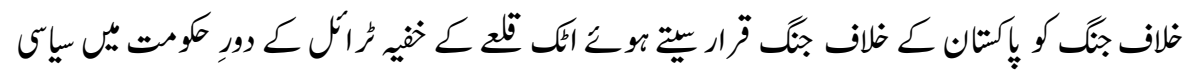

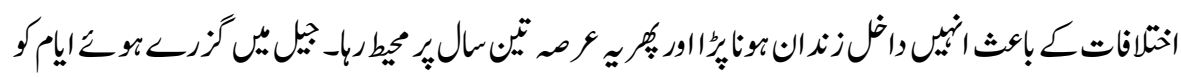

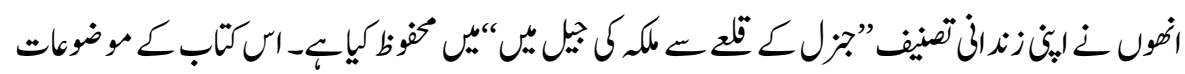

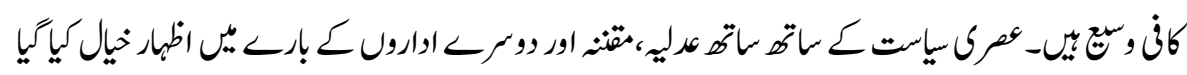

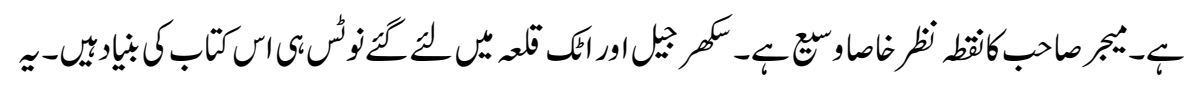

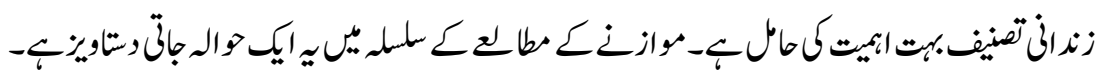

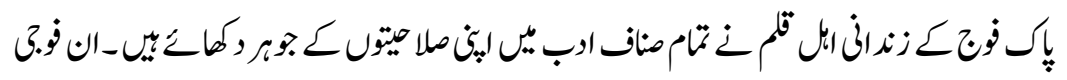

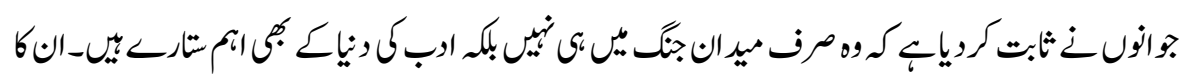

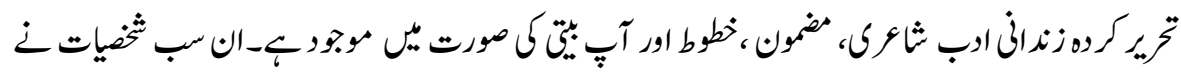

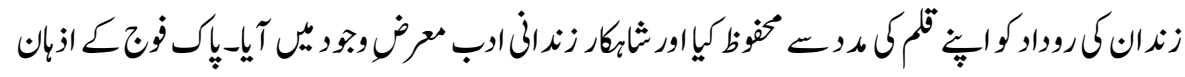

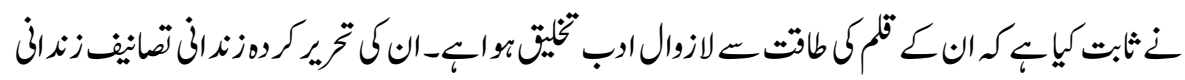

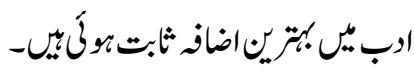

\section{والرجات}

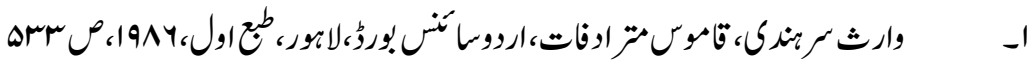

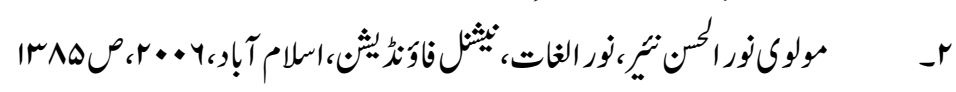




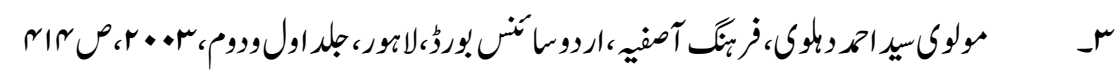

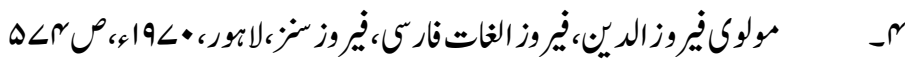

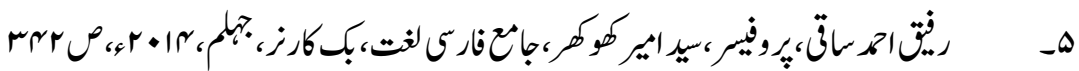

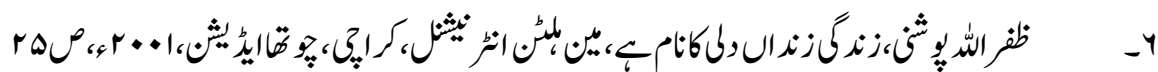

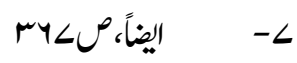

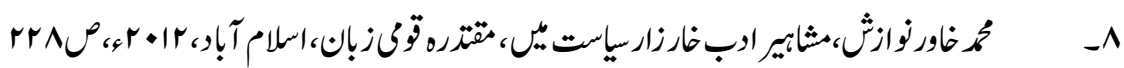

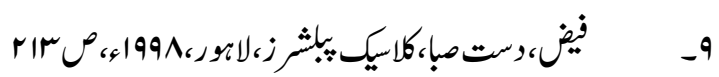

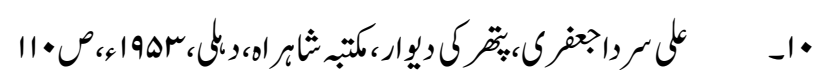

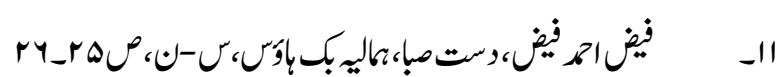

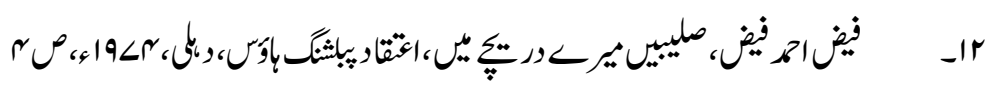

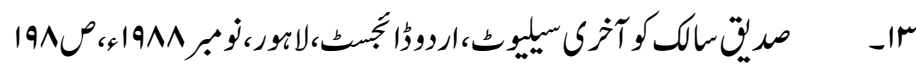

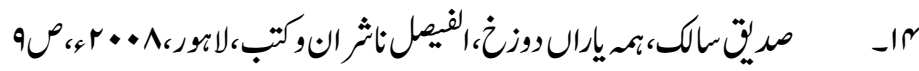

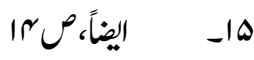

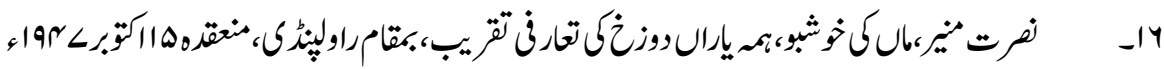

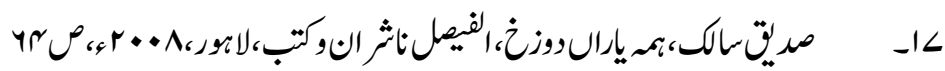

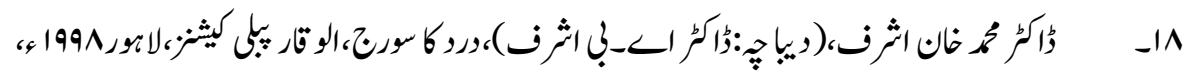

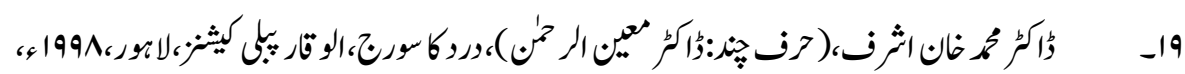
rag اليضاً، 